\title{
The use of Edmodo by supervisor to improve professional competence of Islamic Education teachers
}

\author{
Abidin Sholeh \\ SDN II Krandegan Bulukerto Wonogiri \\ abidinsholeh@gmail.com \\ DOI: 10.18326/mudarrisa.v10i1.99-126
}

\begin{abstract}
This study aims to find out the implementation of Edmodo platform in clinical supervision to improve professional competence of The Islamic Education teacher of Elementary School (SD) in Salatiga in 2017. This research used the action research method. Data retrieval techniques were through observation and interview with descriptive analysis. The results of this study concluded that; First, the average result of observation cycle 1 in stage 1 is 62.32 and in stage 2 is 66.80 with progress increase 4.48 with category $\mathrm{A}$ is 1 person, category $\mathrm{B}$ is 8 people, category $\mathrm{C}$ is 2 people. Secondly, the average result of observation of cycle 2 in stage 1 is 76.52 and 84.40 in stage 2 , with progress increase 7.88 with category $\mathrm{A}$ is 10 people and category B is 1 person. Third, the implementation of the Edmodo platform in clinical supervision can be used to improve the professional competence of The Islamic Education teacher of elementary school by considering the average score level of 65.19 which means that the score is capable of performing clinical supervision to improve the professional competence of The Islamic Education teacher of elementary school.
\end{abstract}

Keywords: Edmodo, clinical supervision, professional competence, MP4 video, Video $3 g p$ 


\section{INTRODUCTION}

Inadequate ratio of supervisors makes it not being maximal in performing supervisor duties and functions. It is necessary for a medium to help improving professional teachers. If the weakness or difficulty of teachers can be improved, it means the quality of learning can be improved, and ultimately the goal of education can be achieved optimally (Iriyani, 2008: 278-285).

This research was conducted based on observation data of one supervisor who foster 94 elementary school teachers and still get additional task to build Kindergarten of Salatiga City. A wide range of supervisors is the reason for the research. Teachers' duties at school are not only teach, this fact makes the structural relationship between teacher and supervisor becomes rare. These barriers need to be solved with the help of the media.

The digital era in the present becomes a must for supervisors and teachers to master technology. By looking at previous research the use of Edmodo is only used by teachers and students only. Seeing the rare opportunity, Edmodo drawn to supervision with reasons of efficiency and effectiveness of work. But for Miarso (2005: 496), he suggests that teachers should be convinced about the usefulness of the technology first and that technology will not replace his position as a teacher but help to at least store and present the concepts, principles and procedures he wants to teach. Moreover, the teachers would need the product if they thought that it was really helpful for them. Otherwise, they would never be interested to try the new product offered. The researchers should think again and again 


\section{Mudarrisa: Jurnal Kajian Pendidikan Islam, Vol. 10, No. 1, 2018}

on the product they plan to develop, whether the product is really needed or not (Jati, 2016: 96).

The familiarity of any social media is definitely influencing the effectiveness of their notifications. The more frequent the users access any social media; the more effective that social medium will be (Jati, 2016: 92). While Jati (2016) preferred to use Facebook Group than Edmodo, Mathupayas Thongmak (2013: 1-15) suggests Edmodo as a private social platform which provides a secure space for teachers and students to connect and to collaborate. Khaleel M. Al-Said (2015: 167) points out findings indicated that students' perceptions of Edmodo and Mobile learning are in "high" level in general, and majority of students have positive perceptions towards Edmodo and Mobile learning since they think that learning using Edmodo facilitates and increases the effectiveness of communication of learning, and they appreciate Edmodo because it saves time. From the theory, it is concluded that Edmodo is a social media used by teachers and students that can be used to help supervisors communicate with teachers in serving the problems faced by each teacher.

According to the Government Regulation of the Republic of Indonesia Number 74 Year 2008 regarding Teachers Chapter IV Working Chairs Article 54 paragraph 8 that the workload of supervisors of educational units, subject supervisors or supervisors of subject groups in performing Teacher professional supervision and training tasks and supervisory equivalent with at least 24 (twenty four) hours of face-to-face learning in 1 (one) week (PP RI 74, 2008: 36). The ratio is not comparable 


\section{Mudarrisa: Jurnal Kajian Pendidikan Islam, Vol. 10, No. 1, 2018}

between the supervisor and the teacher makes the supervisor's work will be more severe because the minimum supervisor also result in additional duty charged become increase.

The effectiveness of e-learning implementation of Edmodo model in learning of Islamic Education on student learning result, case study at SMK Muhammadiyah 1 Sukoharjo using experimental research method concluded that the effectiveness of using Edmodo based e-learning learning media is higher than using conventional learning media $(\mathrm{Nu}$ ' man, 2014). This is contrast with the researcher who reviewed teachers in clinical supervision using action research method.

Another study uses relevant literature sources with descriptive qualitative research methods and literature studies with analysis of various sources in describing and raising new ideas in answering the problematic on the use of e-learning learning media in learning history he concluded that the ideal e-learning is used for difficult lesson materials (Cahyono, 2015). The researcher examines that there are difficulties experienced in the researchers in a particular field. In contrast to the study authors will use in clinical supervision in order to improve the professional competence of teachers.

A study was undertaken at the University of Jambi on the use of Edmodo social networking as a medium of e-learning by senior lecturers who are not accustomed to working with computers on mathematics education courses using qualitative-quantitative methods (Marzal, 2014). In contrast, the authors will utilize Edmodo in the study of supervision. 


\section{Mudarrisa: Jurnal Kajian Pendidikan Islam, Vol. 10, No. 1, 2018}

The development of clinical supervision model with lesson study approach to improve the professional competence of English language teacher of SMA Negeri in Kabupaten Cilacap by using R \& D method concludes that the clinical supervision is compatible with lesson study (Fakhrudin, 2014). Unlike the author, in the methodology, the research is conducted through action research.

However, approximately $62 \%$ of the academic leaders continue to believe online is as good as or better than face-to-face (Allen \& Seaman, 2006; Uzun, 2015). Most believe that serving through online tends to be better than face-to-face. Surely this is very profitable for supervisors who have a ratio more than 1:20 in performing their duties. In line with Erman Uzun, Tony suggests these supervisors an opportunity to improve the quality of their services and take the leap (Renfro-Michel, 2016: 4). And this is in accordance with the rapid development of information technology. In the concept of supervision of supervisors through the principal supervisors in performing their performance, there is a red roaming line between the supervisor to the teacher that is the principal. This is where the Edmodo platform becomes a medium to cut it. Dakwah does not only lecture but also issues ideas, guides and directs the teacher, as Allah says in QS As-Sajdah 32:24, "and We made among them the rulers who gave instructions with our command when they are patient. and they are convinced of our verses."

From the description the authors assert that this research is feasible and the results of his research are needed. With this argument the authors 


\section{Mudarrisa: Jurnal Kajian Pendidikan Islam, Vol. 10, No. 1, 2018}

propose the implementation hypothesis of Edmodo platform in clinical supervision to improve professional competence of teachers PAI of Elementary Schools around Salatiga can improve the professional competence. This study is aimed at teachers and supervisors in the hope that online teachers can communicate and share teachers' problems to supervisors. Supervisors are expected to help teachers' problems to improve their competence in clinical supervision through Edmodo.

\section{METHODS}

Data in the field shows teachers in teaching does not fully make the implementation plan of learning. But the existing learning plan is largely undiscovered so that it looks like a copy-paste. Lack of innovation in the learning process makes students become bored although using teaching aids such as LCD. It is necessary for a creativity and innovation of teachers in teaching every day.

To overcome it, this research done by action research method by adopting McKernan model using at least two times cycle. The first cycle, a researcher examines the problem, needs assessment, idea hypothesis, first action, first action implications, first action evaluation, and the results of the first cycle to be set to continue in the second cycle. The second cycle is essentially the same as the first cycle, and proceeds to decide the results of cycle 1 for the redefinition of the problem, needs assessment, idea hypothesis, action 2, action implication 2, action reevaluation 2, determination of results. To clarify, the scheme is depicted in Figure 1. 
This study uses a qualitative approach to overcome these problems by making the supervisor as a teacher and make the teacher as a student. The steps taken are as follows: 1) Make a needs analysis; 2) Treatment to the supervisor; 3) Supervisors treatment on teachers; 4) Entrance to Cycle 1 by observing two stages; 5) Entrance to Cycle 2 by observing two stages.

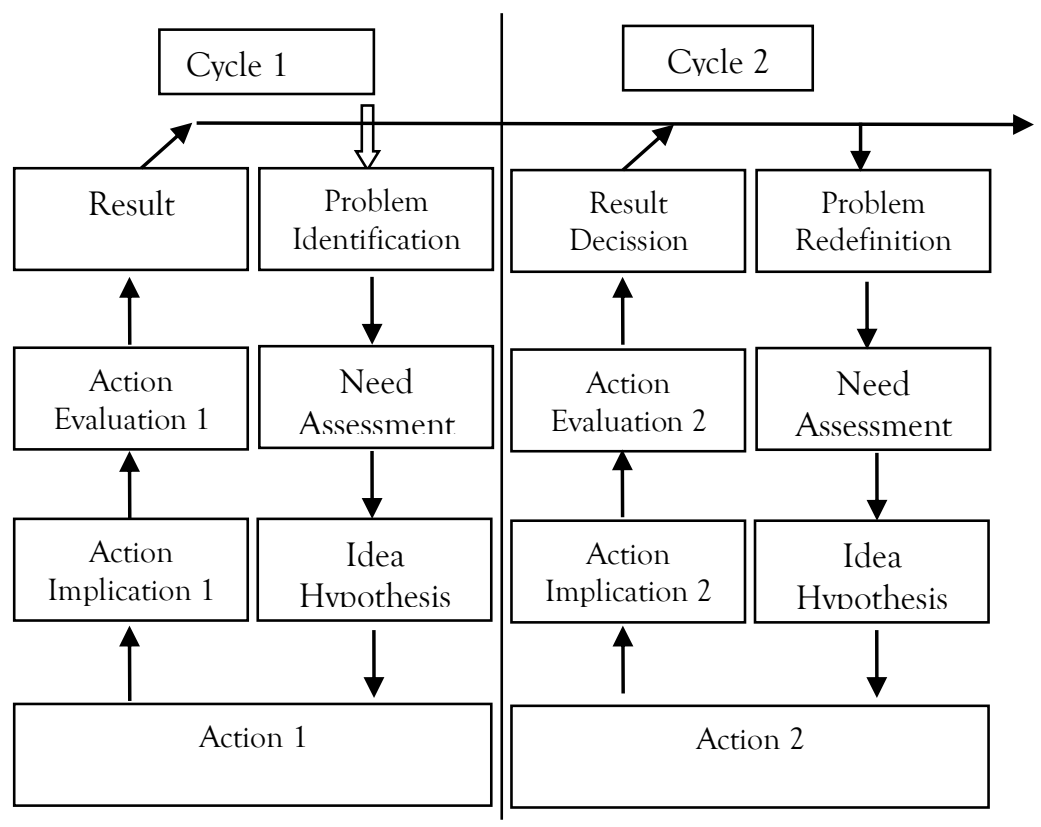

Figure 1. McKernan Scheme Model, in Sukardi (2015: 217)

\section{DISCUSSION}

\section{Understanding Clinical Supervision}

According to M. Ngalim Purwanto (2014: 76) supervision is a coaching activity planned to help teachers and other school staff perform their work effectively. According to Binti Maunah (2009: 24) supervision can be said as a professional service. According to Made Widarta (1992: 250), clinical 


\section{Mudarrisa: Jurnal Kajian Pendidikan Islam, Vol. 10, No. 1, 2018}

supervision is a model of supervision to solve certain problems that have been known before.

Cogan (1984: 2-5) defines clinical supervision with the Resume of The Educational Resources Information Center that clinical supervision as "the rationale and practice designed to improve the teacher's classroom performance, Made Widarta (1992: 250) by elaborating cogan opinions, defining clinical supervision the rational and practice designed to improve the teacher's classroom performance. It takes its principal data from the events of the classroom. The analysis of these data and the relationships between teacher and supervisor from the basis of the program, procedures, and strategies designed to improve the student's learning by improving the teacher's classroom behavior.

Ary H. Gunawan (2011: 207) suggests that clinical supervision is a leadership process in education aimed at assisting the developer of professional teacher candidates, especially in teaching performance based on observation and analysis of data carefully and objectively as guidance for the change of teaching behavior. Rugiyah (2016: 421-431) suggests the definition of clinical supervision adopted from the medical profession that is the process of developing the skills and knowledge of the training participants in the practice.

Howard M Knoff (1988: 240-252) suggests: Collapsing across a number of previous definition, clinical supervision can be defined as an intensive, hierarchical, interpersonally, focused relation, ship involving a supervisor who oversees the development of a supervisee's professional 
kwnoledge skill, confidence, objectivity, and interpersonal interaction on behalf of or with a specified client for the purpose of facilitating and improving competence and effective service delivery and promoting accountability in the field. In line with Howard M Knoff, Charles A Reavis (1976: 360-363) also suggested Clinical supervision rests on the conviction that (rather than items on an evaluation form or items that are pet concerned of the supervisor only). From the above understanding can be concluded for the author, that the clinical supervision is the process of supervisory services on the problems of teachers in helping to improve the competence and performance in implementing the learning process.

\section{Professional Competence}

According to Donni Juni Priansa (2014: 127) professional competence is the ability of mastery of learning materials widely and depth that enables the integration of learning content using ICT and guide learners to meet the competency standards set out in the National Education Standards (SNP, Elucidation of Article 28 paragraph 3 point c). According to Ennar Ratriany Assa (2015: 33) professional competence is the ability of teachers in mastering the learning materials widely and deeply covering all things.

According to the Asian Institute for Teacher Education in his book H.E. Mulyasa, indicators of professional competence in general there are 8 competencies of the 8 translated into 23 important points (2013: 6971). Of the many researchers focused on mastering the materials and deepening of the field of study, managing learning by formulating 
objectives and choosing effective methods, using media and learning resources and create teaching aids in the learning process takes place.

The above description informs that the professional competence of teachers is defined as the authority as well as the responsibilities of a teacher to perform their duties well. However, please note that the competencies that exist in a person do not necessarily show that person is professional in doing the job. Because professional competence not only shows capable in doing the job but also rationally master the responsibility that he is doing with certain concepts and theories, therefore, to be a professional must have four competencies as a teacher; 1) specialist competence; 2) methodical competence; 3) individual competence; 4) social competence.

Thus the contribution of supervisors is important to guide the professional status of teachers in accordance with the predicate through clinical supervision. In line with Kristina Xavier, Louise Shepherd and David Goldstein (2007: 206-209) who proposed clinical supervision is an essential component of professional and personal development. While the teacher is still struggling to get his rights by not looking at it as Government Civil Servant (PNS)/Non PNS must still meet the competence as a teacher.

\section{Needs assessment}

Researchers look for data by making a list of needs analysis which results are taken into consideration for action or treatment of teachers and 
supervisors. The following assessment of the need for teachers is needed in the clinical supervision through Edmodo platform.

Supervisor

Interview with the supervisor is necessary to know the PAI (Islamic Education) teacher who will be the respondent. From the 96 PAI teachers known to have entered the list of emis counted 94 people. The respondents were 20 people. Supervisors in terms of information technology need to get treatment first to be able to use Edmodo platform. While determining the sample that will be the respondent then the supervisor provides recommendations for the determination of the number of respondents as many as 20 PAI teachers in Elementary Schools and set the place in the PSB SDN 01 Kutowinangun Salatiga.

Laptop/Notebook/Desktop/Smarphone

The main priority in this study is the necessary hardware such as laptop/Notebook/Desktop/Smartphone. Therefore investigators through supervisors must ensure PAI teachers in Salatiga for implementation bring a laptop with the aim of more easily accept the explanation and already support with the browser available. The equipment is used to access internet data via $2 \mathrm{G} / 3 \mathrm{G} / 4 \mathrm{G} / \mathrm{Wi}$-Fi network with available network connectivity. To facilitate the respondents in using this then the authors choose a place that is representative with internet facilities in the space PSB SDN Kutowinangun 01 Salatiga. 


\section{Modem/Smartphone}

To connect hardware required a Wi-Fi but when at school or at home need a modem/smartphone. This is used to spread the signal emitted via hotspots that are already available in the modem/smarphone while $\mathrm{Wi}$-Fi on the laptop is to receive hotspot signals and used for access.

Edmodo platform

To run Edmodo platform to the teachers so teachers and supervisors should be able to run Edmodo platform. Some of the things that supervisors and teachers should master are as follows: a) register by e-mail; b) complete the data; c) create groups; d) posting; e) reply to posts; f) attaching file (attached file)

Location

Before conducting training for teachers, researchers and PAI supervisors in Salatiga chose representative places for selected respondents. The chosen place is PSB SDN Kutowinangun 01 Salatiga which has been connected to Wi-Fi to facilitate the training.

Based on the needs assessment, the writer states the idea hypothesis that "the implementation of Edmodo platform in clinical supervision can improve professional competence of PAI teacher in Elementary Schools around Salatiga 2017".

\section{The First Action}

Before introducing the Edmodo platform the author firstly presented about the clinical supervision to provide an understanding because both the 
supervisor had ever conducted a clinical supervision activity and the teacher did not yet know what is meant by clinical supervision. This research uses nonprobability theory with snowball sampling technique. According to the plan, from 20 respondents determined to be samples, 11 teachers and 1 supervisor are willing to be the samples, shown in Table 1 .

Table 1. Clinical Supervision Respondents

\begin{tabular}{cll}
\hline No & \multicolumn{1}{c}{ Name } & \multicolumn{1}{c}{ Work Unit } \\
\hline 1 & Umi Hani & Supervisor \\
2 & Aulia Safiana & SDN 01 Tegalrejo \\
3 & Yeni Purnamasari & SD PTQ An Nida \\
4 & Siti Khoiriyah & SDN 08 Salatiga \\
5 & Arfiyatun & SDN 03 Randuacir \\
6 & Ervina Hasta Dewi & SDN 01 Salatiga \\
7 & Uswatun Hamidah & SDN 01 Dukuh \\
8 & Rafin Nawawi & SDN 03 Kumpulrejo \\
9 & Dwi Sarwanto & SDN 05 Tegalrejo \\
10 & Noviana Heni & SDN 03 Gendongan \\
11 & Rifah Munawaroh & SDN 01 Kumpulrejo \\
12 & Ma'rifatun & SDN 02 Mangunsari \\
\hline
\end{tabular}

Observation on action 1 is that teachers have never conducted clinical supervision activities. Furthermore, the implementation of Edmodo platform for PAI teachers is used in the practice of supervision, especially clinical supervision. The stage is to make the supervisor as a teacher and make the teacher as a student. The successful registration of PAI teachers in the Edmodo platform instantly maximizes the opportunities available to be able to use them.

The next step is the determination of the initial teacher meeting stage with the supervisor. The initial meeting was conducted through the Edmodo platform. Respondents in the initial meeting little by little can access the shipment feature to communicate directly with the supervisor 
and observation plan. It was in this initial meeting that the teacher put forward the problems faced by the supervisor. Supervisor responds by utilizing the incoming notification feature and initiating a conversation by utilizing the feature, as shown in the following figure.

The stage of teacher learning observation, Uswatun Hamidah expressed constraints when teaching using role playing method, and teachers have difficulty in managing learners. Apparently in the division of the group homogeneous, so the active group is always active in the learning activities and the passive also does not follow as it should. Lesson Plan is also not adjusted to what is done. Compatibility between core competencies and basic competencies does not match the indicators made. Previous material has not yet delivered. The challenging questions for students are not expressed with the intention of attracting students' attention. The benefits of the material being studied also have not been delivered at the beginning of the lesson. The spoken and written language also needs to be improved.

At the next meeting, the teacher Uswatun Hamidah and the supervisors do it on the Edmodo platform. One of the most striking of the implementation of the Edmodo platform is that both supervisors and teachers can communicate each other at the initial meeting to determine when observations are made. Before supervisor observations make an assessment instrument review of the Lesson Plans and assess the implementation of teaching. At the feedback meeting the supervisor gives motivation to the teachers who have joined the supervisory group to 
provide direction to the teacher. Motivation or input from the supervisor is given to the teacher concerned through the notification feature. Conversations between teachers and supervisors can only be accessed by supervisors and teachers themselves.

\section{Field Findings}

In the field research process obtained through the first respondent, found: The time allocation in the lesson plan is not appropriate, the key answer and scoring with the questions have not linked the subject matter with the students' experience, have not asked questions that provoke students, have not conveyed the benefits of being learned, the messages delivered are less impressive and have not involved learners in using media, less interaction and responses to learners and have not made students more cheerful, spoken and written language is still mixed, not submitting follow-up and collection of portfolio.

Meanwhile, findings obtained from the second respondent, are: Indicators in the Lesson Plan achievement of competence are not yet appropriate, Not asking questions that provoke students to be actively involved, Not to mention the benefits of what students learn, have not cultivated the active participation of students in learning, oral and written language is still mixed, follow-up plan in the next program has not been delivered.

While the findings obtained from the third respondent, that the relevance of core competencies (spiritual, social, knowledge, and skills) 


\section{Mudarrisa: Jurnal Kajian Pendidikan Islam, Vol. 10, No. 1, 2018}

with basic competence with the formulation of indicators are not yet appropriate, not asking questions that challenge learners to be actively involved, lack of involvement of learners in learning, closing activities of the learning process are not yet optimal.

Then, findings obtained from respondents four, five, and six found that: material suitability with scientific approach has not shown the involvement of learners in media usage, relation with students is still rigid, time relevance with the assessment between the questions and the key answers in lesson plan need improvement of spoken and written language, has not linked previous material on learning, the use of learning resources or media are less attractive, oral language is still mixed or not using standard language, and closing activity of learning process is not yet optimal.

Finding from respondent seven, eight, nine found: relevance of core competence and basic competence with the formulation of indicator in lesson plan have not linked to the material before, have not submitted the benefits derived from the material, need correction of spoken and written language, the suitability between the formulation of competency indicators with the characteristics of learners, apperception activities have not been done as planned, the activity plan has not been delivered, the use of learning resources have not yet carried out according to the lesson plan, The use of media has not been relevant with indicators, Apperception has not linked and demonstrated to the experience of learners, apperception 
time allocation is less perfect, the involvement of learners in learning is less.

The findings obtained from the tenth respondent, among others are as follows; has not made the assessment between the questions and the key answers, the preparation of time allocation is set to the real condition level of difficulty and ease of problems, Apperception is not perfect and require improvement, Involvement of learners to be active in the learning process is not optimal, the language used is still not standard, closing of the learning activities are still not perfect.

While the findings obtained from the eleventh respondent, obtained the data that; there is no suitability of the formulation of competency indicators and planning of learning outcomes that will be achieved by learners, the character of learners and apperception time allocation is not implemented according to the plan that has been stated, the media utilization is still centered by the teacher, the closing activities of the learning process is not perfect.

First Action Implementation

To know category of each PAI teacher or Supervisor of PAI so the author gives a questionnaire related to the Edmodo platform. Based on these data, PAI Supervisors need serious assistance because besides laptop factors that do not support, it is the supervisor's frequency in cyberspace surfing included in the low category. In addition, supervisors in unstructured interviews stated that the Edmodo platform is a novelty and one of the new sciences in teaching activities that are pulled into 
supervision while teachers based on the data Edmodo platform can help to improve their professional competence, especially teaching performance. And the following is the result of action 1 at stage 1 of the Edmodo platform implementation in clinical supervision to improve the professional competence of PAI Teachers.

First Action Evaluation

In the use of Edmodo platform the supervisors find it difficult to use laptops for some reason inversely with the teacher. Suggestions in this case, the supervisor must move the device to know the incoming notification. Technical constraints such as not having modems, smartphones, gadgets experienced by teachers to be very important to anticipate data traffic down. Inaccuracy of teachers in the writing of Lesson Plan often occurs in including the subject matter. Writing indicators that are not in accordance with the problem and the key answers become one of the factors of success in the process of teaching and learning activities. And the most important is good preparation to carry out the teaching and learning process.

Based on the data and factual on the action 1 that need to be evaluated from action 1 in general is as follows: 1) Supervisor is less familiar with the laptop because the condition is less good; 2) Teachers must keep update of technology development; 3) Improvement on the RPP made; 4) When teaching teachers have not fully followed the lesson plan made; 5) Inaccuracy of writing lesson plan in listing learning materials; 6) Question and answer key as well as scoring score.

\section{The Implementation in Cycle 1}


Stage 1

Supervisor observed 11 teachers. In accordance with the plan that is at the planning stage and meetings of supervisors back and teachers communicate with Edmodo. The results of Stage 1 observations are shown in Tabel 2.

Table 2. Scores in cycle 1 stage 1

\begin{tabular}{lllll}
\hline \multirow{2}{*}{ No } & \multirow{2}{*}{ Respondent } & \multicolumn{2}{c}{ Obtained Score } & Average \\
\cline { 3 - 4 } & & Lesson Plan & Observation & \\
\hline 1 & 1 & 63,49 & 56,67 & 60,08 \\
2 & 2 & 66,67 & 60,00 & 63,33 \\
3 & 3 & 65,08 & 63,33 & 64,21 \\
4 & 4 & 66,67 & 63,33 & 65,00 \\
5 & 5 & 68,25 & 66,67 & 67,46 \\
6 & 6 & 76,19 & 76,67 & 76,43 \\
7 & 7 & 66,67 & 70,00 & 68,33 \\
8 & 8 & 63,49 & 60,00 & 61,75 \\
9 & 9 & 61,90 & 53,33 & 57,62 \\
10 & 10 & 57,14 & 46,67 & 51,90 \\
11 & 11 & 55,56 & 43,33 & 49,44 \\
& Average & 64,65 & 60,00 & 62,32 \\
\hline
\end{tabular}

Based on the interval formula $i=\frac{(X t-X r)+1}{K i}$ so

$$
\begin{aligned}
i & =\frac{(76,43-49,44)+1}{4} \\
i & =\frac{26,99+1}{4} \\
i & =\frac{27,99}{4}=7,0
\end{aligned}
$$

Then put in the table to know the rank of teacher who include in category A, B , C, D. The following is an interval observation interval table of Edmodo platform implementation in clinical supervision to improve the professional competence of PAI Teachers. 
Mudarrisa: Jurnal Kajian Pendidikan Islam, Vol. 10, No. 1, 2018

Table 3 . Intervals in cycle 1 stage 1

\begin{tabular}{lll}
\hline Score & Frequency & Category \\
\hline $69,43-76,43$ & 1 & A \\
$62,43-69,43$ & 6 & B \\
$55,43-62,43$ & 2 & C \\
$48,43-55,43$ & 2 & D \\
\hline
\end{tabular}

Thus it can be known: 1) For teachers who enter category $\mathrm{A}$ is 1 person; 2) For teachers who are in category B as many as 6 people; 3) For teachers who enter category $\mathrm{C}$ is 2 people; 4) For teachers who enter category $\mathrm{D}$ is 2 people.

The average score of lesson plan that the supervisor can assess is 64.65. The average score of teachers observed by supervisor is 60.00 The average score of teachers who observed is 62.32 .

Stage 2

Pengawas observed 11 teachers. In accordance with the plan that is at the planning stage and meetings of supervisors back and teachers communicate with Edmodo. Data from the observation result of Stage 2 as follows:

Table 4 . Scores in cycle 1 stage 2

\begin{tabular}{lllll}
\hline \multirow{2}{*}{ No } & Respondent & \multicolumn{2}{l}{ Obtained Score } & Average \\
\cline { 3 - 4 } & & Lesson Plan & Observation & \\
\hline 1 & 1 & 65,08 & 60,00 & 62,54 \\
2 & 2 & 68,25 & 63,33 & 65,79 \\
3 & 3 & 68,25 & 70,00 & 69,13 \\
4 & 4 & 69,84 & 70,00 & 69,92 \\
5 & 5 & 71,43 & 76,67 & 74,05 \\
6 & 6 & 77,78 & 76,67 & 77,22 \\
7 & 7 & 71,43 & 70,00 & 70,71 \\
8 & 8 & 66,67 & 66,67 & 66,67 \\
9 & 9 & 63,49 & 63,33 & 63,41 \\
10 & 10 & 60,32 & 56,67 & 58,49 \\
\hline
\end{tabular}




\begin{tabular}{lllll}
\hline 11 & 11 & 57,14 & 56,67 & 56,90 \\
& Average & 67,24 & 66,36 & 66,80 \\
\hline
\end{tabular}

Based on the interval formula $i=\frac{(X t-X r)+1}{K i}$

$$
\begin{aligned}
& i=\frac{(77,22-56,90)+1}{4} \\
& i=\frac{20,32+1}{4} \quad i=\frac{21,32}{4}=5,33
\end{aligned}
$$

Then, it is included in the table to know the ranks of teacher which enter the categories $\mathrm{A}, \mathrm{B}, \mathrm{C}$ or $\mathrm{D}$.

Table 5. Intervals in cycle 1 stage 2

\begin{tabular}{lll}
\hline Score & Frequency & Category \\
\hline $71,89-77,22$ & 2 & A \\
$66,56-71,89$ & 4 & B \\
$61,23-66,56$ & 3 & C \\
$55,90-61,23$ & 2 & D \\
\hline
\end{tabular}

Thus, it can be known: 1) for teachers who enter category A is 2 people; 2) for teachers who enter category B is 4 people; 3) For teachers who enter category $\mathrm{C}$ as many as 3 people; 4) for teachers who enter category D is 2 people. The average score of lesson plan that the supervisor can assess is 67.24. The average score of teachers who are supervisor observed is 66.36 The average teachers' score observed is 66.80 . Based on the data, the increase from stage 1 to stage 2 in cycle 1 is only 4.48 and it needs to increase again. To simplify, it can be presented in the following graph. 
Mudarrisa: Jurnal Kajian Pendidikan Islam, Vol. 10, No. 1, 2018

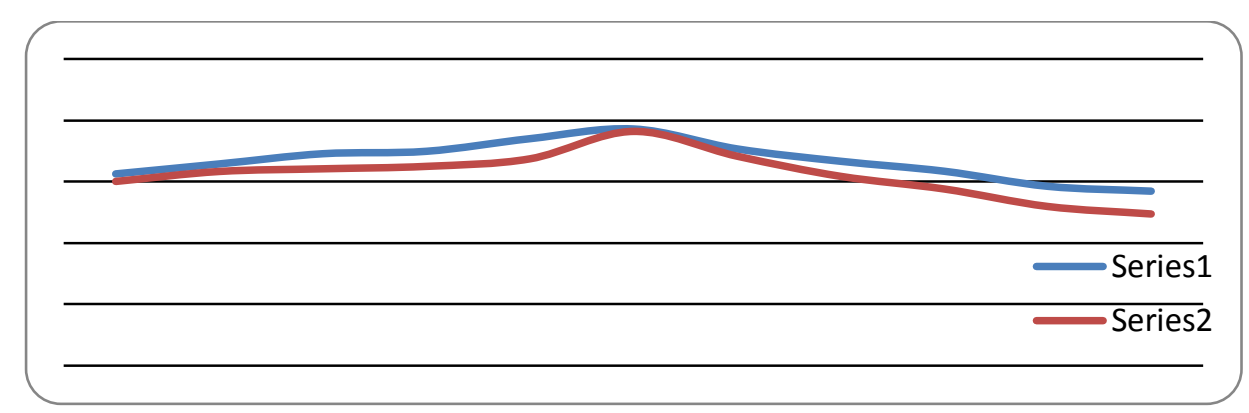

Figure 2. Progress in cycle 1

The Implementation in Cycle 2

Step 1

The supervisor observed 11 teachers. In accordance with the plan that is at the planning stage and meetings of supervisors back and teachers communicate with Edmodo. The results of Stage 1 observations are as follows:

Table 6. Scores in cycle 2 stage 1

\begin{tabular}{lllll}
\hline \multirow{2}{*}{ No } & \multirow{2}{*}{ Respondent } & \multicolumn{3}{l}{ Obtained Score } \\
\cline { 3 - 5 } & & Lesson Plan & Observation & Average \\
\hline 1 & 1 & 73,02 & 73,33 & 73,17 \\
2 & 2 & 74,60 & 76,67 & 75,63 \\
3 & 3 & 77,78 & 76,67 & 77,22 \\
4 & 4 & 80,95 & 80,00 & 80,48 \\
5 & 5 & 80,95 & 83,33 & 82,14 \\
6 & 6 & 82,54 & 80,00 & 81,27 \\
7 & 7 & 79,37 & 76,67 & 78,02 \\
8 & 8 & 74,60 & 80,00 & 77,30 \\
9 & 9 & 71,43 & 76,67 & 74,05 \\
10 & 10 & 69,84 & 76,67 & 73,25 \\
11 & 11 & 65,08 & 73,33 & 69,21 \\
& Average & 75,47 & 77,58 & 76,52 \\
\hline
\end{tabular}

Based on the interval formula $i=\frac{(X t-X r)+1}{K i}$ 


$$
\begin{aligned}
& i=\frac{(82,14-69,21)+1}{4} \\
& i=\frac{12,93+1}{4} \\
& i=\frac{13,32}{4}=3,33
\end{aligned}
$$

Then put in table to know the rank. Thus it can be known: 1) For incoming teachers category $\mathrm{A}$ is 3 people; 2) For teachers who enter category $\mathrm{B}$ as many as 4 people; 3) For teachers who enter category $\mathrm{C}$ as many as 3 people; 3) For teachers who enter category D is 1 person. The average score of lesson plan that can be judged by the supervisor is 75.47 and the average score of the teaching teacher observed by supervisor is 77,58 . The average teacher observed was 76.52 .

Tabel 7. Intervals cycle 2 stage 1

\begin{tabular}{lll}
\hline Score & Frequency & Category \\
\hline $78,81-82,14$ & 3 & A \\
$75,48-78,81$ & 4 & B \\
$72,15-75,48$ & 3 & C \\
$68,82-72,15$ & 1 & D \\
\hline
\end{tabular}

Stage 2

Supervisor observed 11 teachers. In accordance with the plan that is at the planning stage and meetings of supervisors back and teachers communicate with Edmodo. The results are displayed in Table 8.

Table 8 . Scores in cycle 2 stage 2

\begin{tabular}{lllll}
\hline \multirow{2}{*}{ No } & Respondents & \multicolumn{3}{l}{ Obtained Score } \\
\cline { 3 - 5 } & & Lesson Plan & Observation & Average \\
\hline 1 & 1 & 77,78 & 80,00 & 78,89 \\
2 & 2 & 76,19 & 83,33 & 79,76 \\
3 & 3 & 80,95 & 86,67 & 83,81 \\
4 & 4 & 82,54 & 90,00 & 86,27 \\
5 & 5 & 84,13 & 93,33 & 88,73 \\
6 & 6 & 88,89 & 96,67 & 92,78 \\
\hline
\end{tabular}


Mudarrisa: Jurnal Kajian Pendidikan Islam, Vol. 10, No. 1, 2018

\begin{tabular}{lllll}
\hline 7 & 7 & 92,06 & 96,67 & 94,37 \\
8 & 8 & 82,54 & 90,00 & 86,27 \\
9 & 9 & 80,95 & 86,67 & 83,81 \\
10 & 10 & 79,37 & 80,00 & 79,68 \\
11 & 11 & 71,43 & 76,67 & 74,05 \\
& Average & $\mathbf{8 1 , 5 3}$ & $\mathbf{8 7 , 2 7}$ & 84,40 \\
\hline
\end{tabular}

Based on the interval formula $i=\frac{(X t-X r)+1}{K i}$ so

$$
\begin{aligned}
& i=\frac{(94,37-74,05)+1}{4} \\
& i=\frac{20,32+1}{4} \\
& i=\frac{21,32}{4}=5,33
\end{aligned}
$$

Then, it is entered in the table to know the rank. Thus it can be known: 1) for teacher category A is 2 people; 2) for teachers enter into category B as many as 5 people; 3) for teachers who enter category $\mathrm{C}$ as many as 3 people; 4) for teachers who are categorized D is 1 person.

Table 9. Intervals cycle 2 stage 2

\begin{tabular}{lll}
\hline Score & Frequency & Category \\
\hline $89,04-94,37$ & 2 & A \\
$83,71-89,04$ & 5 & B \\
$78,38-83,71$ & 3 & C \\
$73,05-78,38$ & 1 & D \\
\hline
\end{tabular}

The average lesson plan score that supervisor can observe is 81.53 and the average score of the teaching teacher observed by the supervisor is 87.27. Based on the data, the increase of stage 1 to stage 2 in cycle 2 is 7,88 . For simplicity in understanding, the following view is in graphical form. 
Mudarrisa: Jurnal Kajian Pendidikan Islam, Vol. 10, No. 1, 2018

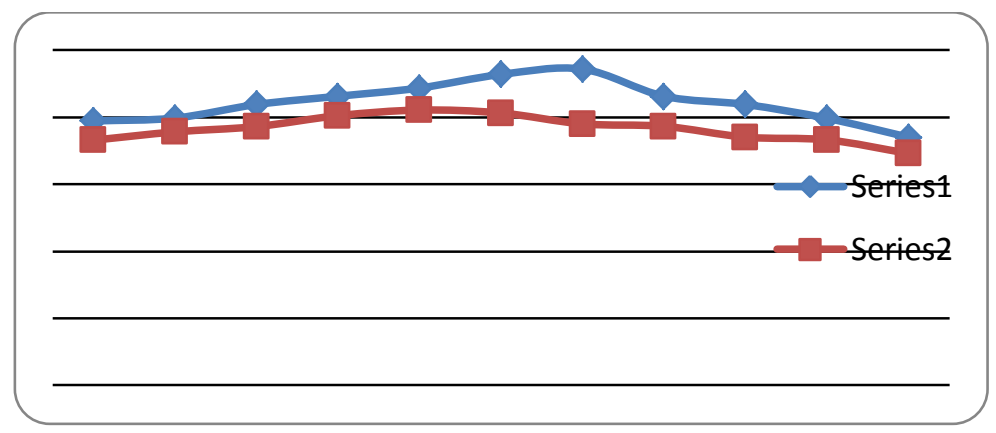

Figure 3. Progress in cycle 2

Based on the study, the implementation of Edmodo platform with average score of 65,19 in clinical supervision can improve professional competence of PAI teacher of Salatiga in 2017 with the average evidence of the results of observation cycle 1 in stage 1 of 62.32 and in stage 2 of 66.80 with a progress increase of 4.48 with category $A$ is 1 person, category B is 8 people, category $\mathrm{C}$ is 2 people which means the implementation of the Edmodo platform in clinical supervision to improve the professional competence of PAI teachers around Salatiga in 2017 can be used to help teacher problems. As well as the average evidence of the results of observation cycle 2 in stage 1 of 76.52 and in stage 2 of 84.40 with a progress increase of 7.88 with category $\mathrm{A}$ is 10 people and category $\mathrm{B}$ is 1 person. It means that the implementation of Edmodo platform in clinical supervision to improve the professional competence of PAI teachers around Salatiga in 2017 can help improve the professional competence of PAI teachers.

Based on the evidence, it can answer the problem of implementing Edmodo platform in clinical supervision to improve the professional 
competence of PAI teachers in Salatiga 2017. That is with the implementation of platform Edmodo the average score of supervisors and teachers of 65.19 was able to carry out clinical supervision and can be used to help improve the professional competence of PAI teachers.

\section{CONCLUSION}

Based on the data, it is possible to answer the hypothesis that Edmodo utilization by supervisors can be used to help improve the competence of PAI teachers. The shortcomings in this study are the limited use of video uploads from teachers because there is a capacity limit of $100 \mathrm{MB}$. And hope the next research is the supervisor can observe through video in utilizing facilities provided by Edmodo.

Based on these conclusions, the researcher gives suggestions for PAI teachers in elementary level to: 1) improve their quality as PAI Teachers and keep update of rapidly developing technology; 2) always actively ask for a solution to the supervisor over the constraints that occur in the teaching and learning process; 3) supervisors of PAI always improve their ability in technology to be one step ahead or equal with PAI Teachers; 4) PAI teachers and supervisors of PAI can utilize Edmodo platform in educational area to coordinate. For further research the authors recommend to examine the planning phase of the learning process, field observation, feedback in the clinical supervision via video. 


\section{REFERENCES}

Al-Said, K. M. (2015). Students' Perceptions of Edmodo and Mobile Learning and their Real Barriers towards Them”, TOJET: The Turkish Online Journal of Educational Technology, 14 (2). 167-168.

Assa, E. R. (2015). Strategy of Learning Hal-Hal yang Boleh dan Tidak Boleh dilakukan oleh Guru saat Mengajar. Yogyakarta: Araska.

Cahyono, Y. D. (2015). E-Learning (Edmodo) Sebagai Media Pembelajaran Sejarah. Jurnal Penelitian. 8 (5). 102-112.

Fakhrudin. Akhmad, S. \& Haryono. (2014). Pengembangan Model Supervisi Klinis dengan Pendekatan Lesson Study untuk Meningkatkan Kompetensi Profesional Guru Bahasa Inggris SMA Negeri Di Kabupaten Cilacap. Journal of Educational Research and Evaluation, 3 (6), 8-17.

Gunawan, A. H. (2011). Administrasi Sekolah Administrasi Pendidikan Mikro, Jakarta: Rineka Cipta.

Iriyani, D. (2008). Pengembangan Supervisi Klinis Untuk Meningkatkan Keterampilan Dasar Mengajar Guru, Jurnal Didaktika, 2 (2). 278 285.

Jati, R. P. (2016). Developing Teachers' Guide to Use Facebook Group in a Blended Writing Course (A Research and Development in IAIN Surakarta). Register Journal, 9 (2): 71-100.

Knoff, H. M. (1988). Clinical Supervision, Consultation, and Counselling: A Comparative Analysis for Supervisors and other Educational Leader's. Journal of Curriculum and Supervision Spring. 3 (3). 240-252.

Marzal, J. (2014). Studi Penggunaan Jejaring Sosial Edmodo Sebagai Media E-Learning Oleh Dosen Senior Yang Tidak Terbiasa Bekerja Dengan Komputer. Edumatica. 4 (4). 37-43.

Maunah, B. (2009). Supervisi Pendidikan Islam Teori dan Praktik. Yogyakarta: Teras.

Miarso, Y. (2005). Menyemai Benih Teknologi Pendidikan diterbitkan atas Kerjasama dengan Pusat Teknologi Komunikasi dan Informasi Pendidikan Pustekkom DIKNAS, Jakarta: Kencana.

Michel, R. Rousmaniere, T. Edina. (2016). Using Technology to Enhance Clinical Supervision. Alexandria: American Counseling Association. 
Mulyasa, H.E. (2013). Uji Kompetensi dan Penilaian Kinerja Guru, Bandung: PT Remaja Rosdakarya.

Nu'man, A. Z. (2014) Efektifitas Penerapan e-learning Model Edmodo dalam Pembelajaran Pendidikan Agama Islam terhadap Hasil Belajar Siswa Studi Kasus pada SMK Muhammadiyah 1 Sukoharjo. Duta, 7(9), 1-13.

Peraturan Pemerintah Republik Indonesia Nomor 74 Tahun 2008 tentang Guru Bab IV Beban Kerja pasal 54 ayat 8, 36.

Priansa, D. J. (2014). Kinerja dan Profesionalisme Guru, Bandung: Alfabeta.

Purwanto, M. N. (2014). Administrasi dan Supervisi Pendidikan, Bandung: PT Remaja Rosdakarya.

Reavis, C. A. (1976). Clinical Supervision A Timely Approach. Education Leadership Journal. 1 (5). 360-363.

Rugaiyah. (2016). Pengembangan Model Supervisi Klinis Berbasis Informasi dan Teknologi, Cakrawala Pendidikan. 35 (3). 421-431.

Sukardi. (2015). Metodologi Penelitian Pendidikan Kompetensi dan Praktiknya. Yogyakarta: Bumi Aksara.

Thongmak, M. (2013). Social Network System in Classroom: Antecedents of Edmodo Adoption, Journal of e-Learning and Higher Education. 2013 (2). 1-15.

U.S. Department of Education National Institute of Education Educational Resources Information Center. (1984). "The Best of ERIC on Educational Management Clinical Supervision”, The Educational Resources Information Centre (Eric), 2 (72). 2-5.

Uzun, E. (2015) Students' Attitude Towards Edmodo as a Supplementary Tool for Higher Education. Participatory Educational Research, 2 (11). 78-83.

Widarta, M. (1992). Pemikiran tentang Supervisi Pendidikan, Jakarta: Bumi Aksara.

Xavier, K., Shepherd, L., \& Goldstein, D. (2007). Clinical supervision and education via videoconference: a feasibility project. Journal of Telemedicine and Telecare, 13(4), 206-209. 